Editorial

\title{
Introduction: Religion and Nationalism? Or Nationalism and Religion? Some Reflections on the Relationship between Religion and Nationalism
}

\author{
Peter C. Mentzel \\ Independent Researcher, Liberty Fund, Inc. 11301 N. Meridian Street Carmel, Indianapolis, IN 46032-4564, USA; \\ pmentzel@libertyfund.org
}

Received: 1 September 2020; Accepted: 22 September 2020; Published: 28 September 2020

\begin{abstract}
This essay is the introduction to the special issue of Genealogy, "For God and Country: Essays on Nationalism and Religion." It poses the question of what relationship, if any, nationalism has to religion, and then briefly reviews the history and current state of the scholarship on the topic. This essay then introduces the seven essays making up the special edition. It concludes by observing that, overall, the collection suggests that while religion and nationalism are more closely related than previously held, they nevertheless remain two distinct phenomena.
\end{abstract}

Keywords: nationalism; religion; Islamism

\section{Introduction}

Religion and nationalism are both powerful and important markers of individual identity, but the relationship between the two has been a source of considerable debate. Much, if not most, of the work done in nationalism studies has been based, at least implicitly, on the idea that religion, as a genealogical carrier of identity, was displaced with the coming of secular modernity by nationalism. Or, to put it another way, national identity, and its ideological manifestation, nationalism, filled the void left in people's self-identification as religion retreated in the face of secular modernity. While a few perceptive students of the subject (e.g., Anthony Smith, Steven Grosby, and Adrian Hastings) made room in their studies for religion, the dominant narrative was that nationalism was a modern phenomenon that has supplanted religion as the primary carrier of identity for most people. The implications were, of course, that religious self-identifications would eventually completely succumb to more secular ones, especially nationalism.

Since at least the late 1990s, however, it has become increasingly apparent that this has not turned out to be the case. Whereas, in some places (e.g., the Republic of Ireland), religion has indeed gone from being one of the most important aspects of personal identity to one of the least, overall, religious identities have proven surprisingly sticky. Perhaps even more interesting, scholars of both religion and nationalism have noticed that these two kinds of self-identifications, while sometimes in tension (as the earlier models explained), are also frequently coexistent or even mutually supportive. A number of different scholarly projects have resulted. What they all have in common is their interest in complicating our understandings of nationalism as primarily a modern, secular phenomenon by bringing religion back into the discussion.

This short introduction to this collection of papers hopes to make some general observations about the state of the current literature on this subject, say a few words about the essays in the collection, and then propose some additional ideas about how to think about the relationship between religion and nationalism in general, and the concept of "religious nationalism" in particular. While conceding that some of the claims of the secular modernist school were too dogmatic, my brief remarks will 
nevertheless conclude that, despite a number of caveats and qualifiers, nationalism remains, essentially, a secular (and probably modern) phenomenon.

\section{Religion and Nationalism}

The current general understanding about the relationship between religion and nationalism is closely tied to what has been called the "Secularization Thesis." The general outlines of the thesis will be familiar to any student of historical sociology: secularization is one of the main characteristics of modernity, and implies the "privatization" of religion. That is, religion gives way to secular understandings of the public self-primarily, national identity.

This narrative owes its origin largely to the two founders of modern sociology, Emile Durkheim (1858-1917) and Max Weber (1864-1920). Durkheim, in his 1912 study The Elementary Forms of Religious Life, took for granted the process of secularization but argued that modern secular existence would prove to be intolerable without some system of beliefs that would provide meaning and purpose to individuals and, perhaps more importantly, some basis for communal life. In pre-modern societies, these needs were filled by religion. In modern, secular societies, the void left by religion is filled by nationalism. According to this reasoning, in this sense, nationalism is a kind of religion, or is perhaps itself a religion.

Max Weber's ideas about nations and nationalism developed over time, and have sometimes been criticized for being incoherent and self-contradictory, or at the very least, vague. One of the few instances where Weber actually offers a definition of what he means by nation was from 1912: "In so far as there is anything common behind this ambiguous word, it must be in the field of politics. The term nation could probably only be defined as: an emotion-based community (Gefülsmäßige Gemeinschaft), whose adequate expression would be a common state, which therefore normally has the tendency to produce just such a state. The causal components however which lead to the emergence of this national feeling can have very different roots." (quoted in Lehne 2010, p. 224) Note that, in this definition, the elements or "components" of the national community are random and undifferentiated. Later, however, Weber moves towards the idea of a nation as having something to do with "culture." "The significance of the 'nation' is usually anchored in the superiority, or at least the irreplaceability, of the culture values (Kulturgüter) that are to be preserved and developed only through the cultivation of the peculiarity of the group." (Weber 1978, p. 925)

While Weber's concepts of nations and nationalism were still in the process of formulation at the time of his death, he had already written a great deal about modernity in general, and secularization in particular. For Weber, the central feature of modernity is Entzauberung, translated, perhaps somewhat misleadingly, as "Disenchantment." It is a broad term, encompassing the "rationalization" of modern societies, and everything that comes with it: parliamentary democracy, bureaucratic administration, capitalism, etc., are all ultimately results of "Disenchantment" and the relentless secularization of society.

Importantly, while Weber situated national identity and nationalism in the context of secular modernity, he did not necessarily link the two in any clear or binding, to say nothing of causal, relationship as Durkheim had done. Yet, there was some sort of connection. In his famous Protestant Ethic and the Spirit of Capitalism, he observed: "The modern man is in general, even with the best will, unable to give religious ideas a significance for conduct of life, culture and national character (Volkscharaktere) which they deserve." (Weber 1958, p. 183 Italics mine).

In any case, most of the literature about the relationship between religion and nationalism is more or less based on some understanding of Durkheim or Weber or, more commonly, both. Even scholars with different approaches to the question of national identity and nationalism (for example, Eric Hobsbawm, John Breuilly, Ernest Gellner, and Benedict Anderson) who otherwise disagree on various points, all situate nationalism, if not national identity itself, unambiguously within the context of secularizing modernity. For all of them (and others), the understanding is that nationalism, as a modern phenomenon, is tied inextricably to secularism. Religious self-identification, 
and especially religion as a primary locus of group loyalty is therefore, by definition, pre-modern (perhaps even anti-modern). To the extent that it continues to exist as a primary site of self or group identification, it is a kind of temporary aberration that must, necessarily, give way in the face of secular modernity.

\section{Critiques of the Secularization/Modernization Thesis}

The Secularization Thesis and, by extension, the close linkage of the modernist theory of nationalism, have come under increasing criticism over the past couple of decades. At its most extreme, these critiques take the form of perennialist or primordialist arguments. Without going into detail here, these positions argue that nations, and perhaps even nationalism, have existed at least since the Middle Ages, and perhaps even earlier. There are disagreements between the two theories about historical continuities of different nations and their particularities, but they are both in agreement that nations and nationalism are not by any means restricted to modernity. Their relationship to the secularist position of the modernists is also interesting. Again, far from linking national identity and nationalism to secularism, perennialist scholars often link these phenomena explicitly to religious identities. Adrian Hastings, one of the most influential of the perennialist theorists, argues explicitly that national identity, and indeed nationalism itself, emerge (at the very latest) during the Renaissance out of different ethnoreligious communities. Another perennialist, Steven Grosby, pushes nations and nationalism far back into ancient history, and, importantly, ties these ancient nations closely to their religions.

An approach that is perhaps somewhere between the modernists and perennialists is what is known, perhaps somewhat awkwardly, as "ethnosymbolists." The preeminent advocate of this approach was certainly the late Anthony D. Smith (d. 2016). This approach argues against both the modernity of national identities (though it is somewhat more inclined to accept the modernity of nationalism as an ideology) and especially against the "functionalist" approach, in which nationalist elites and intellectuals "invent" or "create" nations and nationalism. Instead, Smith contended that nations emerge out of a pre-existing, perhaps even primordial, ethnic compost. These ethnic identities are very old, and are based on shared myths (especially myths of common origin) and, often, religion. (Smith 2000, pp. 62-64) This latter component is especially important in the development of national identities (and especially nationalism itself) when it takes the form of myths of "election" or "chosen-ness." (Smith 1999) The most famous example of this, of course, are the ancient Israelites as the Chosen People, but Smith (and other ethnosymbolists) have discovered such ethnoreligious myths among many other nations: Armenians, Basques, Poles, Irish, and, importantly, Americans. These nations all have, as part of their national mythologies, powerful myths of religious exceptionalism and election, in which they are divinely chosen to perform a powerful mission, which is simultaneously national and religious.

Once the secular modernity approach to nations and nationalism began to be challenged, there are certainly many examples of cases of religious identity trumping or superseding a secular, national one. The rise of the "religious right" or "Christian nationalism" in the USA during the late twentieth century surprised many scholars of nationalism. The horrible Yugoslavian wars of the 1990s likewise were sometimes characterized as religious conflicts (especially in the case of the war in Bosnia-Herzegovina) as were the on-going tensions in places such as Northern Ireland, Lebanon, and Iraq. Perhaps the case of Israeli national identity is the trickiest of all, based as it is on some understanding of a religious identity.

One way of approaching the challenge posed by the seeming persistence of religious identity has been to admit to the general soundness of the Secularization Thesis without tying nationalism to it so tightly. This is the approach of, among others, J. Christopher Soper and Joel Fetzer, who have tried to think of the relationship between nationalism and religion as a kind of "continuum," at one end of which is an ideal-type "secular nationalism" and at the other a fully realized "religious nationalism." Somewhere in the middle, they postulate a "civil-religious nationalism" which partakes of characteristics of both. They have further developed their framework to describe "stable" and 
"unstable" examples of each of these types of nationalism. For example, on one end of the spectrum, they posit Uruguay as an example of a polity with a stable secular nationalism, and India as one with an unstable version. On the other end of the spectrum, they argue that Greek nationalism represents an example of a stable religious nationalism and Malaysia an unstable example. In the middle of the spectrum, they place the United States as a country with a stable civil-religious nationalism and Israel as an example of a polity with an unstable civil-religious nationalism. This approach is interesting because, without jettisoning wholesale the Secularization Thesis, it suggests that nationalism may not be as intrinsically connected to secularization (and modernity) as modernist students of nationalism studies would argue. "For many people in those countries [in Africa and Asia] the modernizing, secular state which privatized religion had little purchase because religion provided a stronger basis for self-identification than did secular, nationalist values. The result was the rise of a religious nationalism in much of the developing world that hewed much more closely to the spiritual, cultural, and historical allegiances of the masses." (Soper and Fetzer 2018, p. 6) Furthermore, "ideologically, this form [religious nationalism] of nationalism 'makes religion the basis for the nation's collective identity and the source of its ultimate value and purpose on this earth.'" (Soper and Fetzer 2018, p. 7) Perhaps the most interesting insight of their framework is their "middle" category of civil-religious nationalism, where "nationalism is itself seen as a secularized form of religion" or, to put it another way, "nationalism is itself essentially a form of religion." Yet, importantly, "unlike secular nationalism, civil-religious nationalism was not an attempt to usurp religion, but neither was it simply the marrying of nationalism with a particular religious tradition [which, in their model, they call 'religious nationalism']". As they continue: "Like modernization theory, civil religion presumes that the modern state is in some respects replacing the role traditionally played by the church, but it challenges the secular presumption of modernist accounts in recognizing that the state retains a need for moral legitimacy, something that civil religion can provide." (Soper and Fetzer 2018, p. 9).

If most of the non-modernist theories about nations and nationalism make some room for the Secularization Thesis, if not actual concessions to some of the modernists' claims, Atalia Omer and Jason A Springs in their book Religious Nationalism reject almost all of arguments of modernists and secularists. Their central claim is that "it is both analytically inadequate and factually incorrect to claim that secular and religious forms of nationalism are clearly and distinctly separable and stand as opposites to each other." (Omer and Springs 2013, p. 40) In fact, they find (though they do not explicitly say so) that most manifestations of nationalism can actually be described as "religious nationalism." This may be because of their broad interpretation of what it means for "religion" to influence "nationalism." They identify three main ways in which religion "produces and reproduces identity and community [including national communities]." These include "institutional support; social segregation; and how ritual practices, symbol systems, mythic understandings, as well as theological concepts give meaning to, structure, and reinforce social and political identifications." (Omer and Springs 2013, p. 9).

A different approach to the study of religion and nationalism has been proposed by Rogers Brubaker, who, without proposing a categorical architecture himself, has offered "views" or "strategies" for studying this relationship. (Brubaker 2011) These four "approaches" to ways of examining the relationship between nationalism and religion are: 1 . Treating religion and nationalism as "analogous phenomena." In its boldest formulation, this would treat nationalism as a kind of religion, or simply as a religion. This seems to correlate to approaches that would map onto the category of "civil-religious nationalism", as developed by Soper and Fetzer. 2. Using religion to "explain things about nationalism-its origin, its power, or its distinctive character." In the literature, this is more or less the approach of scholars such as Anthony Smith and Adrian Hastings, both of whom argue that modern nationalism, emerges out of a religious compost, especially the category of "chosen-ness." 3. Treating "religion as part of nationalism." That is, religion and nationalism are intertwined or imbricated, yet distinct, phenomena. This is probably what most scholars, including Soper and Fetzer, would recognize as "religious nationalism." 4. Posting a "distinctly religious form of nationalism." This is the trickiest, but also most intriguing of his categories. This approach claims that "religious 
nationalism is a distinctive kind of nationalism." That is, it is not a claim that nationalist symbols and rhetoric often draw upon religious images and language, nor that nationalism and religion can exist in a symbiotic or intertwined relationship, nor even that modern nationalism emerges somehow out of religious culture. Rather, "it is a claim that there is a distinctive religious type of nationalist program that represents a distinct alternative to secular nationalism." (Brubaker 2011, p. 12) Brubaker singles out the work of Roger Friedland as a prime example of this kind of approach. In particular, Friedland argues that "Islamism" constitutes such an example of a "distinctly religious form of nationalism."

\section{Review of the Chapters}

The seven essays that make up this collection offer some interesting case studies of the relationship between religion and nationalism, onto which we might try to apply some of the above outlined analytical tools.

As it turns out, the kinds of approaches used by the authors map on very easily to those postulated by Brubaker. His first category, in which nationalism is explored as a kind of religion, is the approach taken in Spyridon Tegos' essay "Civility and Civil Religion before and after the French Revolution: Religious and Secular Rituals in Hume and Tocqeville." (Tegos 2020).

Most of the contributors in one way or another treated their topics in terms of Brubaker's second category, "using religion to explain things about nationalism-its origin, its power, or its distinctive character." This is very clearly at the intellectual core of the papers on Orthodox Christianity and nationalism by Georgios Steiris, and by Dragan Šljivić and Nenad Živković. (Steiris 2020; Šljivić and Živković 2020) These papers are also very interesting for challenging the entire secularist argument that nationalism is necessarily a product of secular modernity. Drawing on Anthony D Smith's "ethnosymbolist" theories, Šljivić and Živković present three case studies examining the different ways that autocephalous ecclesiastical processes and nation building in Southeastern Europe were (and are) closely linked. Interestingly, in their account, the causal arrows are not always pointed in the same direction. In some cases, the autocephalous project seems to precede the nationalist one, whereas it seems to follow from it in others. Prof. Steiris makes an argument that partakes of both perennialism and ethnosymbolism for the Medieval roots of Greek national identity. He argues that Byzantine intellectuals, beginning as early as the thirteenth century, had developed a distinctly Greek national identity based not only on Orthodox Christianity and its rich repertoire of symbols, but on Classical Greek history as well.

A treatment of religion and nationalism that places it firmly in the context of modernity is the contribution of Danielle Ross. (Ross 2019) This important paper is a perfect example of Brubaker's third "approach," in which nationalism (and in this case socialism as well) and religion are intertwined or imbricated. Using very different historical material (and a different religion) Mark Edwards' study of the development of "Christian nationalism" in the USA also seems to me a case of religion and secular American nationalism intertwining to produce the phenomenon of "Christian (American) nationalism." (Edwards 2019) The same approach is evident in Yvonne Chiu's study of Buddhism in Burma/Myanmar. Burmese national identity and nationalism are profoundly intertwined with Theravada Buddhism, while both remain nevertheless distinct sources of identity. (Chiu 2020).

Joyce Janca-Aji gives us a very different look at a possible relationship between Buddhism and national identity, if not nationalism. (Janca-Aji 2020) I do not, frankly, see how this fascinating essay maps onto any of Brubaker's "approaches." Janca-Aji's question is how a "foreign" religion such as Buddhism interacts with American history and culture in the self-identity of converts. She suggests that the process can (or perhaps, might) create a new kind of identity, partaking of both.

Finally, Steven E. Grosby, a leading theorist in perennialist approaches to nationalism studies, offers some ideas about the relationship between nation (if not nationalism) and religion. (Grosby 2019) The main aim of Professor Grosby's essay is to tease out how (or if) national identity (not to say nationalism itself) and religion are related. He finally comes to the conclusion that the category of religion occupies a distinct aspect of human self-consciousness. "The category of religion-for both 
the pre-axial and axial ages- represents the configuration of thought ... and conduct in response to the problem of the ordeal of human consciousness about the mystery of the universe, specifically, whether or not there is meaning to its order, and the place of both the individual and his or her society within it." Further, "the character of religion ... indicates that it is a distinctive orientation of human consciousness, that is, it is not derivative of another orientation." (Grosby 2019, p. 14) These conclusions seem to call into question the entire category of what we call "religious nationalism" in that the two phenomena are presented as distinct categories. Or, perhaps more accurately, the two categories exist (and have historically existed) in a state of constant tension, representing, as they do, two "autonomous orientations of the human mind, of which religion is one, and the territorial kinship of the nation, is another." Sometimes, as in the monolatrous pre-axial age religions, this relationship is very close, while the distinction is clearer at others (in particular in the monotheistic religions of the axial age).

This line of argument puts Grosby's position more or less in Brubaker's second "approach." That is, in Grosby's account, religion, and especially the crucial development from pre-axial- to axial-age religion, helps explain the development of nationalism. Importantly, however, Grosby's account presents nationalism (or at least national identity) as being as ancient as religion, and not something that develops out of it or from it (as in the accounts of Smith or Hastings, for example). Rather, national and religious identities have always existed, expressing, as they do, two "distinctive orientations of human consciousness."

\section{Conclusions}

The seven contributions to this collection provide some very different approaches to the central question posed by this volume: the relationship between nationalism and religion. In the process, they also raise some interesting challenges to the pervading "modernist" orthodoxy in the field of nations and nationalism studies. Yet, one is struck by the fact that none of these essays (with the exception of Professor Grosby's contribution) necessarily contradicts the essential features of the "Secularization Thesis." While all of them provide ample evidence of the important linkages and relationships, of various kinds, between religion and nationalism, none of them (again with the possible exceptions of Grosby's and perhaps Janca-Aji's) demonstrate the dominance of "religion" over "nationalism" as a candidate for the decisive site of personal identity. While most of these contributions argue (persuasively, I think) for the tremendous influence religion and religious identities have had in the development of national identities, and even nationalism itself, at the end of the day, we are still left with cases in which a basically secular understanding of the nation is left as the main element in any nationalist narrative. This is certainly not to say that we lack examples of religion's continued capacity to provide symbols or rhetoric to a nationalist movement, but the actual content of a modern nationalist project remains nevertheless basically secular.

This is once again where "Islamism" or "Islamic Fundamentalism" offers such a challenge. Is Islamism a nationalist ideology and are groups such as Islamic State nationalist? These movements are political (like secular nationalist movements) in that they seek to control states, or perhaps more accurately, establish new states. However, the intellectual content of these movements is universal, not national. The foot soldiers of al-Qaeda or the Islamic State were/are a multinational group, all subsumed within the universalist Islamist ideologies of those organizations. As one scholar, writing on Hassan al-Banna and Sayyid Qutb (arguably the intellectual godfathers of modern political Islamism), notes "nationalism tends to see the freedom and greatness of the national community as a goal in itself. At least theoretically, this is not the case with the Islamic umma, which explicitly points beyond itself, and sees itself merely as a vehicle for facilitating man's relationship with God." (Brykczynski 2005, p. 15) Now, one could argue that the "nation" on which organizations such as Islamic State are built are defined religiously. Indeed, the term "umma," usually translated as the "community of believers (in Islam)," can also be translated as "nation." However, I think that we must be careful here. As Rogers Brubaker has perceptively warned, "nationalism is a useful concept only if it is not overstretched." (Brubaker 2011, p. 14) That is, terms such as "nation" and "religion" are useful 
and expansive but they are not infinitely elastic. A religious community and a national one, if they are to maintain any sort of analytical rigor, must be kept conceptually separate. As Professor Grosby points out in his contribution to this collection, this might not always have been the case, as with the pre-axial-age monolatrous religions. However, it does become very problematic when dealing with a universalist, axial-age religion such as Islam (or, for that matter, Christianity). The national identities and nationalist movements of almost all historically Muslim nations (Arabs first and foremost but Iranians, Malays, Turks and others as well) have been tremendously influenced by Islam and have drawn freely and deeply on the rich cultural and symbolic storehouse provided by it. Yet, all of these movements, even the ostensibly "fundamentalist" Iranian revolution of 1979, were ultimately best understood as nationalist in character. They were, inter alia, concerned with issues recognizable to any other secular nationalist movements: the glorification and strengthening of the nation (even if the nation was largely described in terms of religion).

Groups such as the Islamic State are clearly different. Even though its immediate goals, such as those of a nationalist movement, involved the establishment of a state, the motivation for those goals and the ultimate vision of that state were quite different. The membership of the state was not limited to a certain group but was, in fact, explicitly intended to someday account for all people on Earth (who had been converted one way or another to Islam). Similarly, the goals of the state were not the glorification of a nation (even if religiously defined) but the implementation of God's will and law on Earth.

In an essay on the relationship between nationalism, religion, and secularism, Talal Asad wrote: "If the secularization thesis no longer carries the conviction it once did, this is because the categories of politics and religion turn out to implicate each other more profoundly than we thought, a discovery that has accompanied our growing understanding of the powers of the modern nation-state. The concept of the secular cannot do without the idea of religion." (Asad 1999, p. 192) As the contributions to this volume demonstrate, Asad's assertion must be broadly correct. Yet, the "concept of the secular" and the "idea of religion" continue to exist as two distinct, yet complementary, aspects of human consciousness.

Funding: This research received no external funding.

Acknowledgments: I thank Steven Grosby who initially recommended me for the position of guest editor for this project, and the editors of Genealogy, especially Simi Wang, for their encouragement and support.

Conflicts of Interest: The author declares no conflict of interest.

\section{References}

Asad, Talal. 1999. Religion, Nation-State, Secularlism. In Nation and Religion: Perspectives on Europe and Asia. Edited by Peter van der Veer and Hartmut Lehmann. Princeton: Princeton University Press.

Brubaker, Rogers. 2011. Religion and Nationalism: Four Approaches. Nations and Nationalism 18: 2-20. [CrossRef] Brykczynski, Paul. 2005. Radical Islam and the Nation: The Relationship between Religion and Nationalism in the Political Thought of Hassan al-Banna and Sayyid Qutb. History of Intellectual Culture 5: 1-19.

Chiu, Yvonne. 2020. Non-Violence, Ascetism, and the Problem of Buddhist Nationalism. Genealogy 4: 94. [CrossRef]

Edwards, Mark. 2019. From a Christian World Community to a Christian America: Ecumenical Protestant Internationalism as a Source of Christian Nationalist Renewal. Genealogy 3: 30. [CrossRef]

Grosby, Steven. 2019. Once Again Nationality and Religion. Genealogy 3: 48. [CrossRef]

Janca-Aji, Joyce. 2020. Whose Dharma Is It Anyway? Identity and Belonging in American Buddhist (Post)Modernities. Genealogy 4: 4. [CrossRef]

Lehne, Jakob. 2010. Max Weber and Nationalism: Chaos or Consistency? Max Weber Studies 10: 209-34. [CrossRef] Omer, Atalia, and Jason A. Springs. 2013. Religious Nationalism. Santa Barbara: ABC-CLIO.

Ross, Danielle. 2019. The Age of the 'Socialist-Wahhabi-Nationalist Revolutionary': The Fusion of Islamic Fundamentalism and Socialism in Tatar Nationalist Thought, 1898-1917. Genealogy 3: 58. [CrossRef]

Šljivić, Dragan, and Nenad Živković. 2020. Self-Ruled and Self-Consecrated Ecclesiastic Schism as a Nation-Building Instrument in the Orthodox Countries of South Eastern Europe. Genealogy 4: 52. [CrossRef] 
Smith, Anthony D. 1999. Ethnic Election and National Destiny: Some Religious Origins of Nationalist Ideals. Nations and Nationalism 5: 331-55. [CrossRef]

Smith, Anthony D. 2000. The Nation in History: Historiographical Debates about Ethnicity and Nationalism. Lebanon: University Press of New England.

Soper, J. Christopher, and Joel S. Fetzer. 2018. Religion and Nationalism in Global Perspective. Cambridge: Cambridge University Press.

Steiris, Georgios. 2020. History and Religion as Sources of Hellenic Identity in Late Byzantium and the Post-Byzantine Era. Genealogy 4: 16. [CrossRef]

Tegos, Spyridon. 2020. Civility and Civil Religion before and after the French Revolution: Religious and Secular Rituals in Hume and Tocqueville. Genealogy 4: 48. [CrossRef]

Weber, Max. 1958. The Protestant Ethic and the Spirit of Capitalism. New York: Charles Scribner's Sons. First published 1905.

Weber, Max. 1978. Economy and Society. Berkeley and Los Angeles: University of California Press.

(C) 2020 by the author. Licensee MDPI, Basel, Switzerland. This article is an open access article distributed under the terms and conditions of the Creative Commons Attribution (CC BY) license (http://creativecommons.org/licenses/by/4.0/). 